DOI: https://doi.org/10.32838/2523-4803/70-6-19

удК 338

\title{
Каличева Н.С.
}

доктор економічних наук, доцент,

доцент кафедри економіки та управління виробничим і комерційним бізнесом,

Український державний університет залізничного транспорту

\section{Політаєв Д.Б.}

магістр,

Український державний університет залізничного транспорту

Kalicheva Natalia, Politaiev Dmytro

Ukrainian State University of Railway Transport

\section{ВПЛИВ СУЧАСНОГО РИНКУ НА ФОРМУВАННЯ ОРГАНІЗАЦІЙНО-ЕКОНОМІЧНИХ СКЛАДНИКІВ ІННОВАЦИЙНОЇ ДІЯЛЬНОСТІ ПІДПРИЕМСТВ}

\begin{abstract}
Стаття присвячена вирішенню наукового та прикладного завдання щеодо дослідження теоретико-методичних і прикладних засад впливу трансформачії ринкового середовища на інновачійну діяльність підприємств. Окреслено головні чинники впливу макроекономічного середовища на інноваційний розвиток підприємств. Доведена доцільність формування організаційно-економічних складників інноваційного розвитку підприємства із визначенням закладеної в інновації иінності. Сформована необхідність визначення комерціалізації новацій під час їх поширення на ринку. Обтрунтовано, щзо саме проблеми комериіалізації інновацій визначають конкурентоспроможність підприємства, а інноваційно-інвестиційні процеси лежать в основі забезпечення його ефективного розвитку в поточній та довгостроковій перспективі.
\end{abstract}

Ключові слова: інновачї, споживча ијіність, комерціалізація, розвиток підприємств, конкурентоспроможність, ефективність, ринкова економіка.

Постановка проблеми. Нині на розвиток світової економіки мають істотний вплив проривні інновації, до яких відносяться штучний інтелект, хмарні технології та великі бази даних, розроблення нових підходів щодо генерування технологій тощо. Це приводить не лише до необхідності трансформації підходів ведення господарської діяльності в усіх виробничих та невиробничих сферах, а й до зміни інструментів здійснення інноваційної діяльності. Адже пошук шляхів успішного виведення на ринок інноваційних технологій не лише $\epsilon$ запорукою ефективного та конкурентоспроможного розвитку підприємства, але й стає вимогою часу.

Аналіз останніх досліджень і публікацій. Питання забезпечення ефективного інноваційного розвитку сучасного підприємства розкриті у роботах В.Л. Диканя, О.О. Захаркіна, А.П. Колеснікова, О.Є. Кузьміна, Ю.И. Мельника, О.Г. Шевлюги та інших науковців [1-5], які внесли істотний доробок у цю тематику. Проте більшість їхніх праць спрямована на забезпечення ефективного інноваційного розвитку конкретних сфер народного господарства або певних технологій. Але в реаліях нашої країни досить важко знайти правильний шлях розвитку, особливо коли відбувається постійна трансформація зовнішнього середовища. Адже ефективний розвиток підприємства із використанням інноваційних технології, в тому числі 3 високим рівнем інтелектуалізації, стикається зі значною кількістю проблем як методико-прикладного, так і інституційного характеру.

Постановка завдання. Метою статті $\epsilon$ дослідження проблематики інноваційного розвитку підприємств $з$ урахуванням сучасних передумов та особливостей формування ринкового середовища. Адже саме від недостатнього врахування рівня впливу сучасного ринку на інноваційну діяльність підприємств гальмуються всі процеси розвитку їхнього технологічного оновлення.

Виклад основного матеріалу дослідження. Сучасний розвиток світової економіки характеризується значними темпами інноваційного зростання. Відбувається перехід на актуалізацію цінності знань як основного потенціалу виробничих систем. Знання стають джерелом становлення нових форм організації бізнесового середовища та економічного зростання. Вони трансформуються в уміння та виділяються в інноваційних технологіях, стають базою підвищення ефективності взаємодії суб'єктів у межах інноваційної діяльності країн, формують підходи до забезпечення розвитку національного господарства та добробуту населення [6].

Необхідно зазначити, що нині більшість інноваційних досліджень проводять заклади вищої освіти 
та наукові установи, технопарки, бізнес-акселератори тощо, а не спеціалізовані відділи на підприємствах. За таких умов підприємства змушені звертатися до цих організацій для налагодження взаємозв'язку щодо придбання та освоєння різних технологічних новацій. Сьогодні це є одним із основних міжнародних способів поширення інноваційних технологій, забезпечення технологічного розвитку підприємств, регіонів тощо. За таких умов вивчення сучасних особливостей ведення інноваційної діяльності вітчизняними підприємствами є базою для покращення наявної інноваційної інфраструктури та розроблення стратегічних пріоритетів інноваційного розвитку нашої країни.

Нині глобалізаційний розвиток економіки відобразився і на формуванні політики інноваційної діяльності, зокрема жодна із провідних світових країн не може здійснювати інноваційну діяльність в усіх галузях народного господарства. На це є об'єктивні причини, серед яких основною виступає наявність ресурсів. Тому кожна країна світу може стати частиною глобального світового інноваційного процесу шляхом ефективного використання наявного ресурсного потенціалу.

В нашій країні нині досить гостро стоїть проблема щодо ефективного використання природно-ресурсного потенціалу. Це пов'язано із відсутністю дієвих якісних підходів до здійснення діяльності щодо охорони навколишнього середовища, браком заходів щодо забезпечення їхньої комерційної привабливості, нестачею можливостей для ефективного використання ресурсів навколишнього природного середовища, кризою еколого-економічного розвитку, малою зацікавленістю у формуванні екологічної економіки тощо [7]. Позитивним у розвитку вітчизняних підприємств є збільшення кількості запроваджених інноваційних технологічних процесів та зростання кількості промислових підприємств, котрі виготовляють інноваційну продукцію, що переважає рівень зростання загальної кількості промислових підприємств, які запроваджують інновації. Зокрема, вітчизняні підприємства серед основних видів інноваційної діяльності виокремлюють придбання машин, обладнання та програмного забезпечення для виробництва нових або значно поліпшених продуктів та послуг; здійснення діяльності щодо запровадження нових або суттєво вдосконалених продуктів чи процесів, а саме: техніко-економічне обгрунтування, тестування, розроблення програмного забезпечення для поточних потреб, технічне оснащення, удосконалення організаційних та виробничих процесів тощо. Також необхідно відзначити, що з кожним роком в нашій країні відбувається зменшення загальної кількості промислових підприємств і збільшення кількості підприємств, які впроваджують інновації. Але ці позитивні зрушення є досить незначними, оскільки частка реалізованої інноваційної продукції в загальній структурі промислового виробництва досить мала, що говорить про низький рівень інноваційної діяльності вітчизняних підприємств [8].

Відзначимо, що розвиток сучасної української економіки вимагає негайної модернізації промисловості та розвитку інноваційної діяльності підприємств. Цього можливо досягти за рахунок розроблення організаційно-економічних складників інноваційних технологій підприємств, що виражається через систему управління підприємством як сукупність дій та заходів із визначеними закономірностями, функціями, принципами, формами та методами організації інноваційної діяльності підприємства, застосування яких необхідне для досягнення цілей та підвищення його ефективного розвитку (рис. 1).

Необхідно зазначити, що в умовах трансформації ринкового середовища розроблення організаційноекономічних складників інноваційної діяльності промислових підприємств є основним чинником забезпечення їхньої інвестиційної привабливості. Адже фінансово-економічна криза останніх років призвела до зниження інноваційної активності вітчизняних підприємств, тому для забезпечення конкурентоспроможності та ефективного розвитку на підприємстві варто сформувати на базі його технічних, фінансових, організаційних, наукових та кадрових характеристик організаційно-економічні складники забезпечення інноваційної привабливості підприємства. Це дасть змогу:

- забезпечити безперервність техніко-технологічного розвитку підприємства;

- організувати безпечний виробничий процес шляхом застосування таких матеріалів, обладнання та технологічних процесів, котрі не призведуть до негативного впливу на життя та здоров'я працівників, навколишне середовище у вигляді відходів та шкідливих викидів;

- забезпечити відповідність технологічного обладнання та технологічних процесів запитам наукового прогресу;

- узгодити всі складники підсистем та елементів управління підприємством в умовах постійної трансформації ринкової економіки;

- максимізувати прибуток;

- розвивати комплексність регулюючих і забезпечувальних механізмів, що впливають на діяльність підприємства 3 боку зовнішнього середовища, економічного механізму підприємства, інструментів та методів управління техніко-технологічним розвитком підприємства тощо;

- утримувати наявні та розвивати нові конкуренті переваги $з$ метою завоювання та отримання на ринку кращих позицій, ніж у конкурентів;

- забезпечити високу оперативність та гнучкість управлінської та виробничої систем підприємства;

- орієнтувати підприємство на застосування науково обгрунтованих управлінських систем;

- спрямовувати виробничу та господарську діяльність підприємства на задоволення потреб і запитів споживачів.

Результатом інноваційної діяльності підприємства має бути отримання економічного ефекту, тобто у підприємства мають зрости фінансово-економічні показники діяльності, збільшитися рівень конкурентоспроможності [9]. Це можна досягти шляхом постійних змін 


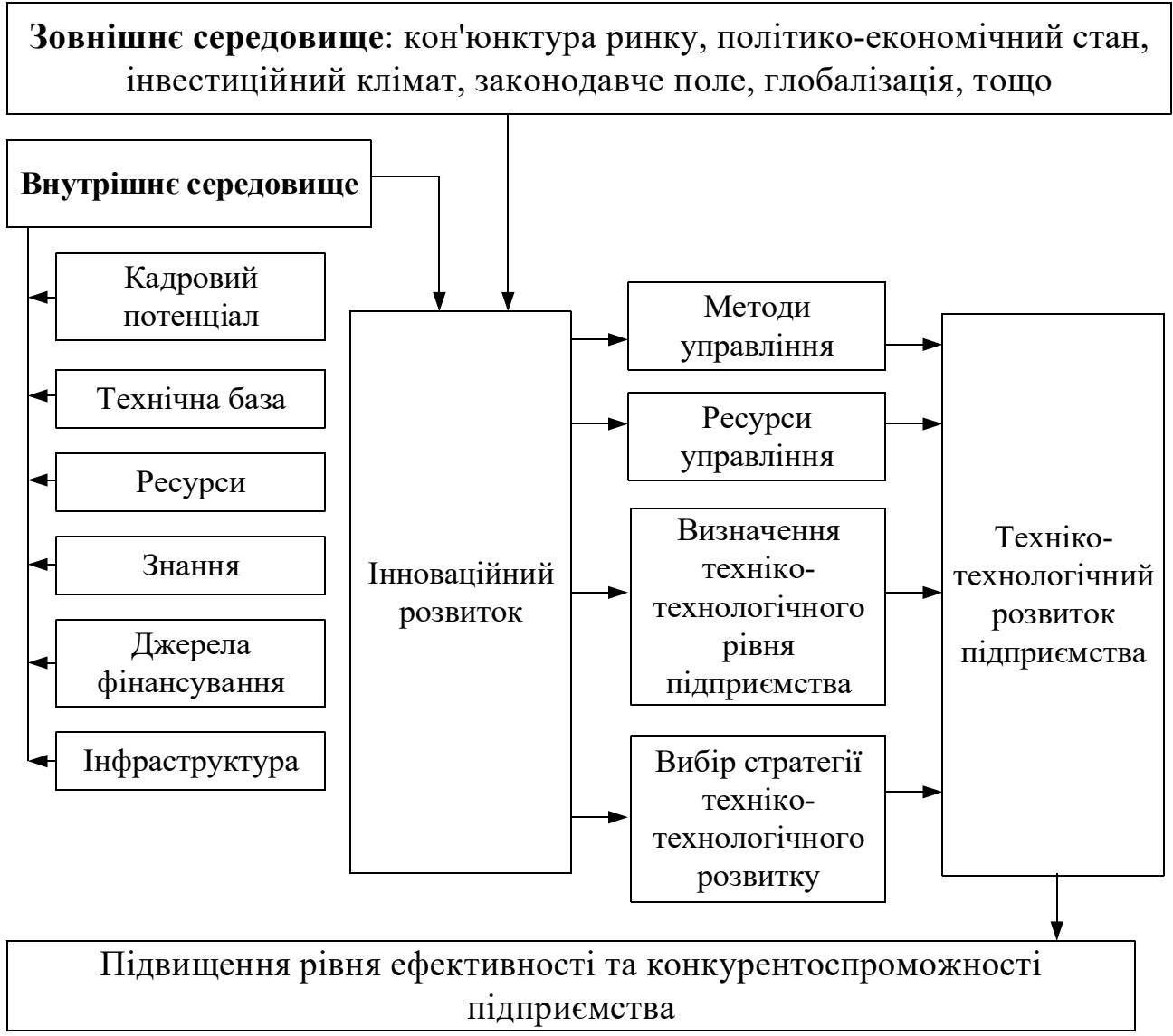

Рис. 1. Структурно-логічна схема організаційно-економічних складників стимулювання інноваційної привабливості промислових підприсмств

та удосконалень, що буде безпосередньо відображатися на отриманих результатах, а своєчасне внесення трансформацій та коректив дасть змогу усунути «вузькі» місця та виокремити проблемні зони в системі господарювання.

Необхідно відзначити, що економічне обгрунтування інноваційної діяльності підприємства має тісний взаємозв'язок із комерціалізацією інновацій. Адже визначення цінності новацій з погляду наявності на них ринкового попиту формує конкурентоспроможність інноваційних технологій підприємства. Досягти цього можна за рахунок економічного оцінювання технологій, що зводиться до такого:

- визначити потребу в новації на ринку та провести попередню характеристику іiї цінності;

- зробити оцінку кількісних та якісних характеристик інновації;

- дослідити бізнес-перспективи;

- оцінити процеси комерціалізації інноваційного продукту та доцільність поширення на ринку;

- провести аналіз нових знань на ринку, які 3'явилися як наслідок комерціалізації новацій, для розроблення наступних інноваційних проєктів.
Таким чином, система формування організаційноекономічних складників інноваційного розвитку підприємства має бути спрямованою на удосконалення його технічної та технологічної бази, визначення складників споживчої цінності інновацій, встановлення рівня комерціалізації для підвищення ефективності його діяльності та збільшення рівня конкурентоспроможності.

Висновки 3 проведеного дослідження. Узагальнюючи викладене вище, необхідно зазначити, що теоретичні і практичні проблеми інноваційного розвитку підприємств завжди посідали провідне місце серед наукових досліджень. Тож нині, коли світова економічна система знаходиться на етапі постіндустріального розвитку, який характеризується значним динамізмом та нестійкістю, формування інноваційної привабливості підприємства є тим чинником, застосування якого дасть змогу потенційним інвесторам об'єктивно оцінювати власні ризики, а керівникам підприємств - впроваджувати відповідні методи прискорення темпів інноваційного розвитку з метою підвищення ефективності виробництва та досягнення вищого рівня конкурентоспроможності. 
Список літератури:

1. Дикань В.Л. Концепція інноваційного розвитку економіки України. Вісник економіки транспорту і промисловості. 2015. Вип. 52. С. 9-20.

2. Захаркін О.О. Роль інновацій у нарощенні вартості українських підприємств. Маркетинг $і$ менеджмент інновачій. 2014. № 3. С. 90-101.

3. Колесніков А.П., Петрик С.І. Об'єктивні передумови та напрямки оновлення техніко-технологічної бази підприємств. Сталий розвиток економіки. 2011. № 1. С. 150-153.

4. Кузьмін, О.Є., Мельник, Ю.М., Сагер, Л.Ю. Сигида, Л.О. Теоретичні аспекти формування стратегій комерціалізації інноваційної продукції. Вісник Одеського національного університету. Серія: Економіка. 2019. Вип. 1. С. $69-73$.

5. Шевлюга О.Г., Олефіренко О.М. Дослідження впливу технологічних інновацій на ринок технологій і розвиток підприємства. Вісник СумДУ. Серія «Маркетинг і.менеджмент інновацій». 2011. № 4. URL: http://mmi.fem.sumdu.edu.ua (дата звернення: 20.10.2020).

6. Каличева Н.Є., Масан В.В., Старцев Д.С. Вплив техніко-технологічних інновацій на ефективний розвиток підприємства. Вчені записки Таврійського національного університету імені В.І. Вернадського. Серія: Економіка і управління. 2018. Т. 29 (68). № 5. С. 51-54.

7. Соціально-економічний потенціал сталого розвитку України та іiі регіонів: національна доповідь / за ред. Е.М. Лібанової, М.А. Хвесика. Київ : ДУ ІЕПСР НАН України, 2014. 776 с.

8. Дащенко Н.М., Філиппова С.В. Технологічне оновлення інноваційно-орієнтованих промислових підприємств: інвестиційні потреби та їх забезпечення : монографія. Одеса : ОНПУ, ФОП Бондаренко М.О., 2016. 225 с.

9. Каличева Н.Є., Алєксєєнко В.І. Роль інноваційних процесів у забезпеченні конкурентоспроможності промислових підприємств в умовах ринкової економіки. Причорноморські економічні студіï. 2019. Вип. 41. С. 49-52.

\section{References:}

1. Dykan V.L. (2015) Kontseptsiia innovatsiinoho rozvytku ekonomiky Ukrainy [The concept of innovative development of the economy of Ukraine]. Bulletin of Economics of Transport and Industry, vol. 52, pp. 9-20.

2. Zakharkin O.O. (2014) Rol innovatsii u naroshchenni vartosti ukrainskykh pidpryiemstv [The role of innovation in increasing the value of Ukrainian enterprises]. Marketing and innovation management, no. 3, pp. 90-101.

3. Kolesnikov A.P., Petryk S.I. (2011) Obiektyvni peredumovy ta napriamky onovlennia tekhniko-tekhnolohichnoi bazy pidpryiemstv [Objective preconditions and directions of updating the technical and technological base of enterprises]. Sustainable economic development, no. 1, pp. 150-153.

4. Kuzmin O.Ye., Melnyk Yu.M., Saher L.Yu. Syhyda L.O. (2019) Teoretychni aspekty formuvannia stratehii komertsializatsii innovatsiinoi produktsii [Theoretical aspects of formation of strategies of commercialization of innovative production]. Bulletin of Odessa National University. Series: Economics, vol. 1, pp. 69-73.

5. Shevliuha O.H., Olefirenko O.M. (2011) Doslidzhennia vplyvu tekhnolohichnykh innovatsii na rynok tekhnolohii i rozvytok pidpryiemstva [Research of influence of technological innovations on the market of technologies and development of the enterprise]. Bulletin of SSU. Marketing and Innovation Management Series, no. 4. Available at: http://mmi.fem.sumdu.edu.ua (accessed 20 October 2020).

6. Kalycheva N.Ye., Masan V.V., Startsev D.S. (2018) Vplyv tekhniko-tekhnolohichnykh innovatsii na efektyvnyi rozvytok pidpryiemstva [Influence of technical and technological innovations on the effective development of the enterprise]. Scientific notes of Tavriya National University named after VI Vernadsky. Series: Economics and Management, vol. 29 (68), no. 5, pp. 51-54.

7. Libanova E.M., Khvesyk M.A. (Eds.) (2014) Sotsialno-ekonomichnyi potentsial staloho rozvytku Ukrainy ta yii rehioniv: natsionalna dopovid [Socio-economic potential of sustainable development of Ukraine and its regions: a national report]. Kyiv: Public Institution "Institute of Environmental Economics and Sustainable Development of the National Academy of Sciences of Ukraine". (in Ukrainian)

8. Dashchenko N.M., Filyppova S.V. (2016) Tekhnolohichne onovlennia innovatsiino-oriientovanykh promyslovykh pidpryiemstv: investytsiini potreby ta yikh zabezpechennia : monohrafiia. [Technological renewal of innovation-oriented industrial enterprises: investment needs and their provision: a monograph]. Odesa: ONPU, FOP Bondarenko M.O. (in Ukrainian)

9. Kalycheva N.Ye., Alieksieienko V.I. (2019) Rol innovatsiinykh protsesiv u zabezpechenni konkurentospromozhnosti promyslovykh pidpryiemstv $\mathrm{v}$ umovakh rynkovoi ekonomiky [The role of innovation processes in ensuring the competitiveness of industrial enterprises in a market economy]. Black Sea Economic Studies, no. 41, pp. 49-52. 


\section{ВЛИЯНИЕ СОВРЕМЕННОГО РЫНКА НА ФОРМИРОВАНИЕ ОРГАНИЗАЦИОННО-ЭКОНОМИЧЕСКОЙ СОСТАВЛЯЮЩЕЙ ИННОВАЦИОННОЙ ДЕЯТЕЛЬНОСТИ ПРЕДПРИЯТИЙ}

Статья посвящена решению научного и прикладного задания по исследованию теоретико-методических и прикладных основ влияния трансформации рыночной среды на инновачионную деятельность предприятий. Определены главные факторы влияния макроэкономической среды на инновационное развитие предприятий. Доказана целесообразность формирования организаџионно-экономических составляющих инноваџионного развития предприятия с определением заложенной в инноваџии иенности. Сформирована необходимость определения коммерцииализации новаций при их распространении на рынке. Обосновано, что именно проблемы коммерциализации инноваций определяют конкурентоспособность предприятия, а инновационно-инвестиционные прочессы лежат в основе обеспечения его эффективного развития в текущей и долгосрочной перспективе.

Ключевые слова: инновации, потребительская иченность, коммерииализация, развитие предприятий, конкурентоспособность, эффективность, рыночная экономика.

\section{INFLUENCE THE MODERN MARKET ON THE FORMATION OF THE ORGANIZATIONAL AND ECONOMIC COMPONENT OF THE INNOVATION ACTIVITY ENTERPRISES}

At present, the development of the world economy is significantly influenced by breakthrough innovations, which include artificial intelligence, cloud technologies and large databases, the development of new approaches to technology generation and others. This leads to the need to transform not only the approaches to doing business in all productive and non-productive areas, but also to change the tools for innovation. After all, the search for ways to successfully bring innovative technologies to market is not only the key to efficient and competitive. There are objective reasons for this, among which the main one is the availability of resources. Therefore, every country in the world can become part of the global global innovation process through the effective use of available resource potential. In our country today the problem of efficient use of natural resource potential is quite acute. This is due to the lack of effective quality approaches to environmental protection, lack of measures to ensure their commercial attractiveness, lack of opportunities for efficient use of environmental resources, the crisis of ecological and economic development, low interest in the formation of ecological economy, etc. enterprises, but also becomes time consuming. The development of the modern Ukrainian economy requires immediate modernization of industry and development of innovative activities of enterprises. This can be achieved through the development of organizational and economic components of innovative technologies of enterprises, which is expressed through the management system of the enterprise as a set of actions and measures with certain patterns, functions, principles, forms and methods of organizing innovative activities of the enterprise. Effective development. In the conditions of transformation of the market environment development of organizational and economic components of innovative activity of the industrial enterprises is the basic factor of maintenance of their investment attractiveness. After all, the financial and economic crisis of recent years has led to a decrease in innovation activity of domestic enterprises, so to ensure competitiveness and effective development of enterprises should be formed on the basis of its technical, financial, organizational, scientific and personnel characteristics organizational and economic components to ensure innovative attractiveness. Thus, the system of formation of organizational and economic components of innovative development of the enterprise should be aimed at improving its technical and technological base, determining the components of consumer value of innovations, establishing the level of commercialization to increase efficiency and increase competitiveness.

Key words: innovation, consumer value, commercialization, enterprise development, competitiveness, efficiency, market economy. 